\title{
Talinum paniculatum (Jacq) Gaertn (Java ginseng) Production using Vesicular-Arbuscular Mycorrhizal
}

\author{
Sulistiono ${ }^{1}$, Alfinda Novi Kristanti ${ }^{2}$ and Agus Muji Santoso ${ }^{1}$ \\ ${ }^{1}$ Biology Education Department, Faculty of Training Teacher and Education, University of \\ Nusantara PGRI Kediri, East Java, Indonesia \\ ${ }^{2}$ Chemistry Department, Faculty of Science and Technology, Airlangga University, Surabaya, \\ Indonesia
}

\begin{abstract}
Soil pathogen is one of main problem in Java ginseng production in tropical field. This study was aimed to evaluate the impact of VAM application to Java ginseng tuber production. Application of VAM was conducted in various concentrations $(0,1,2$, and $3 \%)(w / w)$. Thin Layer Chromatography was used to detected saponin and spectrophotometry was used to determine total saponin. Biomass, the number of rotten tuber, and total saponin were determined after eleven months under greenhouse condition. Inoculation $3 \%$ of VAM can enhance the number of healthy and biomass Java ginseng tuber significantly. But the application of VAM did not increase total saponin content.
\end{abstract}

\section{Article History}

Received 23 November 2017

Accepted 30 December 2017

Keyword

Saponin

Vesicular-Arbuscular

Mycorrhizal

Soil Pathogen

Talinum paniculatum

\section{Introduction}

Java ginseng (Portulacaceae) is an herbaceous medicine of tropical plant. The plant is widely used as active compounds source, such as saponins, flavonoids, tannins, triterpenes or sterols, and polyphenols. Java ginseng has been known for its effectiveness as inducer on spermatogenesis and motility of sperm, anti-inflammatory, androgenic potency, and sperm viability (Saroni et al., 1999; Sumastuti, 1999; Winarni, 2009; Rahmi et al., 2011). Saponins are glycosylated secondary metabolites distributed in plant tissues (Hu et al., 2003). Santoso et al. (2016) was reported that Java ginseng rich of Ginsenosides, an important triterpenoid saponin as well as the other ginsengs. Java ginseng is a potential medicinal plant with activity as good as other medicinal plants such as Korean ginseng or another ginseng from other countries.

There are many previous studies revealed the efficacy of Java ginseng, but its production in Indonesia has not been optimal yet. There are some factors which inhibit Java ginseng production in Indonesia, such as the lack information of good cultivation techniques in field. Java ginseng plantation in field also has its own some challenges, such as tuber-eating nematode which attack the plant and cause tuber rotten as well as soil pathogens do. This 
case has been recorded on Sewon Bantul Yogyakarta and Plosoklaten Kediri (East Java Provice) Indonesia as the central of Java ginseng production.

Vesicular-Arbuscular Mycorrhizal (VAM) is vesicle formed by fungi which have a benefit on plant growt (Sikes, 2010; Gazey et al., 2004; Al-Karaki \& Al-Raddad, 1997) because it can absorb phosphor in optimum amount plants needed to survive in drought condition (Nurhayati, 2010; Berta et al., 1995). It also protects plants from pathogens (Rianto et al., 2005; Gazey et al., 2004; Simanungkalit, 1997). For example, a Glomus sp. fungus on VAM has capability in inhibition of several microbial pathogens activity which causes plant wilting, such as Pseudomonas solanacearum (Rianto et al., 2005). Plant with mycorrhizal roots can absorb $\mathrm{Zn}$ and $\mathrm{S}$ from the ground faster than plant with non-mycorrhizal root (Ruiz-Lozano et al., 1995; Abbott et al., 1992). This means that VAM application is promising in increasing the Java ginseng production in Indonesia.

One problem of Java ginseng tuber production in Indonesia is the lack information of good planting techniques. This research is important because the results will help to obtain information about good planting techniques which can be applied by farmers to provide healthy tuber of Java ginseng.

\section{Materials and Methods}

\section{Application of VAM}

Java ginseng seeds were collected from field in Plosoklaten Kediri East Java during dry season from May to August 2013. Java ginseng seed were obtained by cutting the dry flower panicles. Seeds were germinated in tray and taken at 21 days after germination. Germinated Java ginseng then transferred into poly-bags filled with soil and sand (1:1) and planted for 2 weeks. The seedlings then inoculated with VAM in some concentration $(0,1,2$, and $3 \%)(w / w)$. VAM inoculates which used in this research were obtained from Biotechnology Center, Bogor Agricultural Institute. Plants were treated for 8 months with liquid compost supplementation. Weeding and pest controlling were done during the treatment. Java ginseng roots were harvested by cutting the stem base at $3-4 \mathrm{~cm}$ from the surface of planting medium. Planting medium with root was given water until saturated then the plastic bag was cut on one side and root can be released slowly. Furthermore, ginseng roots were cleaned from soil particles using tap water. Roots were obtained biomass under $70^{\circ} \mathrm{C}$ until constant condition (g). Healthy tubers per plant was evaluated by counting of rotten bulb using this formula (rotten bulb index = [NR/NHR]; NR is the number of rotten bulb of tuber per plant and NHR is the number of healthy tuber per plant)

\section{Determination of Saponin Content}

Saponin content of air dried Java ginseng bulbs were measured through qualitative, semi quantitative and quantitative methods (Santoso, 2012). One gram of dried samples was grinded into fine powder in room temperature. Extraction was done by maceration using $80 \%$ of ethanol for 3 times then saturated in water bath on $80^{\circ} \mathrm{C}$ until shrunk into $0,1 \mathrm{~mL}$. Detection of Java ginseng root saponin content has been done using Thin Layer Chromatography (TLC) method using propanol and water (14:3). Chromatograms then was removed, dried at room temperature, and sprayed with anisaldehid $-\mathrm{H}_{2} \mathrm{O}_{2}$, followed by heating at $110^{\circ} \mathrm{C}$. The saponin existence will be presented by dark green to black spot. While quantitative test performed by spectrophotometer $(365 \mathrm{~nm})$ with $80 \%$ of ethanol which reacted with vanillin reagent. TLC and quantitative test were calculated according to the method as described by Santoso 
(2012). All chemical reagents were purchase in pro analysis grade by Sigma.

\section{Data Analysis}

Biomass and total saponin were performed by one-way analysis of variance (ANOVA) using the statistical software SPSS for Windows. Duncan's multiple range tests were used to evaluate significant difference between means at a significant level $(P<0.05)$. Biomass and saponin spot in chromatogram were evaluated descriptively.

\section{Results and discussion}

VAM inoculation was conducted in Java ginseng successfully for 8 months under greenhouse condition. Application of VAM can enhance of biomass (Table 1) and the number of healthy Java ginseng tuber (Table 2). There were a significant increase of biomass and the number of healthy Java ginseng tuber. In the present research. Higher biomass can be obtained by adding $3 \%$ of VAM $(11,11 \pm 0,49$ g per plant) but inoculation of $2 \%$ can provide healthy tuber of Java ginseng. In control group, the number of rotten bulb up to $28 \%(0,28)$ (Figure 1B) and tended to decrease in 1\% VAM inoculation.

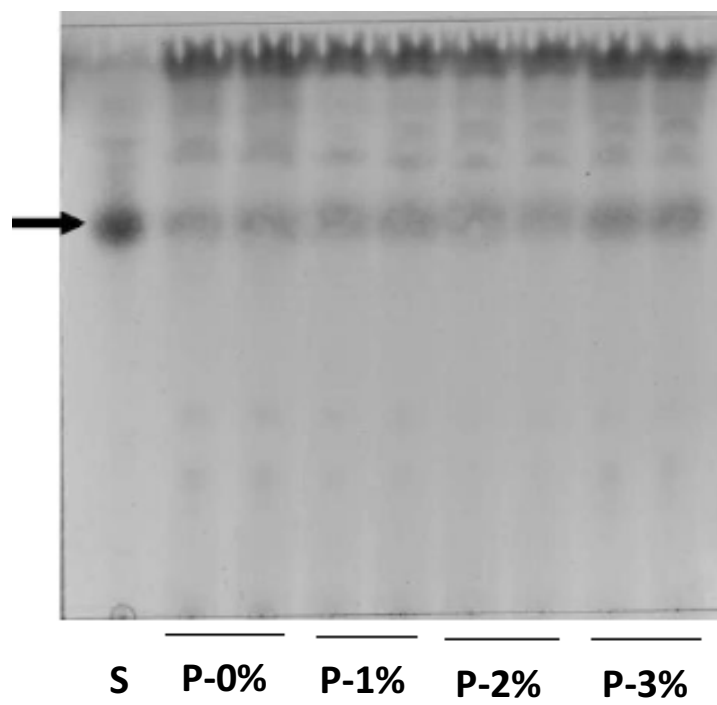

(A)

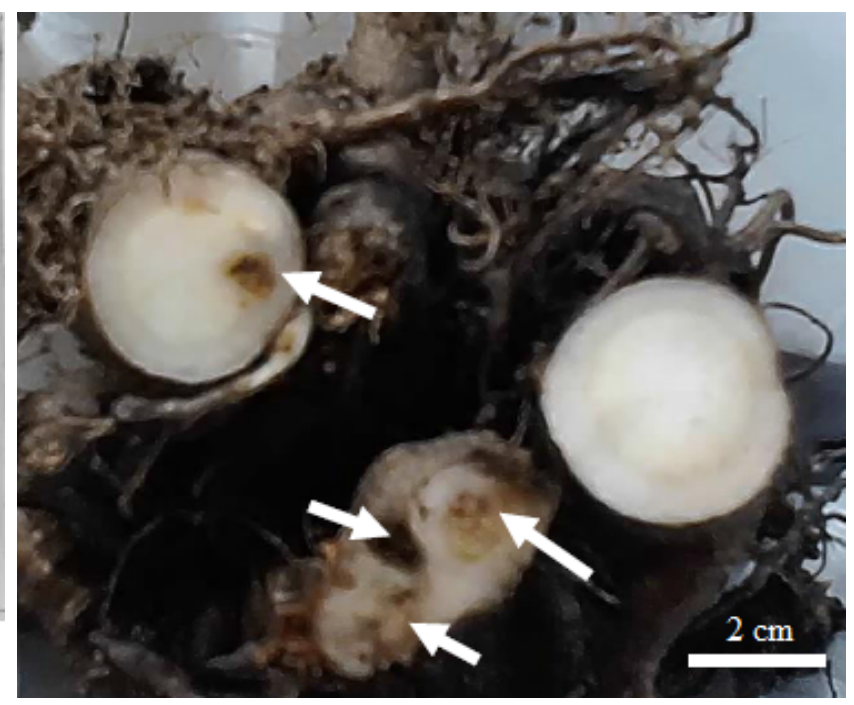

(B)

Figure 1. Thin Layer Chromatography of Ethanol Extract of Java Ginseng Tuber after VAM Inoculation on Silica Gel (standard saponin = S) $(A)$ and spot of rotten bulb in control group caused pathogen (white arrow) (B).

Table 1. Biomass of Java Ginseng tuber after VAM inoculation (g)

\begin{tabular}{cc}
\hline Treatment & Biomass (g) \\
\hline P-0\% & $9,16 \pm 1,42^{\mathrm{c}}$ \\
P-1\% & $10,21 \pm 0,84^{\mathrm{a}}$ \\
P-2\% & $10,61 \pm 0,78^{\mathrm{a}}$ \\
P-3\% & $11,11 \pm 0,49^{\mathrm{b}}$ \\
\hline
\end{tabular}

*Different letters in the same column indicate significant differences at the level of Duncan test $(P<0.05)$

In order to evaluate saponin content, TLC was used and be confirmed quantitatively by using spectrophotometry method. Both of TLC and spectrophotometry method were done successfully. All samples contain rich saponin. It can be confirmed by the same color of spot 
which appear on chromatograms as the color of saponin standard (Figure 1A). Thus, the result indicated that there was no significant total saponin of Java ginseng tuber after VAM inoculation (Table 3). The present study revealed that VAM inoculation in Java ginseng can enhance the biomass and improving the healthy tuber but did not total saponin.

Table 2. Root number of Java Ginseng on 8 months after VAM inoculation.

\begin{tabular}{cc}
\hline Treatment & Rotten bulb \\
\hline P-0\% & 0,28 \\
P-1\% & 0,11 \\
P- $2 \%$ & - \\
P-3\% & - \\
\hline
\end{tabular}

*Rotten Parts

Table 3. Saponin content on Java Ginseng tuber ( $\mathrm{mg} / \mathrm{g}$ sample)

\begin{tabular}{cc}
\hline Treatment & Saponin Content \\
\hline P-0\% & $13,33 \pm 0,3055^{\text {a }}$ \\
P-1\% & $13,34 \pm 0,8083^{\text {a }}$ \\
P- $\%$ & $13,23 \pm 0,5133^{\text {a }}$ \\
P-3\% & $13,37 \pm 0,3055^{\text {a }}$ \\
\hline
\end{tabular}

*Different letters in the same column indicate significant differences at the level of Duncan test $(P<0.05)$

VAM application on plant is expected to give benefit on plant growth (Berta et al., 1995; Michelsen \& Rosendahl, 1990). The benefit for plant is VAM can provides some essential nutrients such as $\mathrm{P}, \mathrm{Mg}, \mathrm{K}, \mathrm{Fe}$, and $\mathrm{Mn}$ (Setiadi, 1989). VAM has ability to form colony as mycorrhizal hyphae on root surface (Rianto et al., 2005; Al-Karaki et al., 2004; Berta et al., 1995). This hyphae extension helps root in nutrients intake, especially in nutrient-poor conditions, low pH, and lack of water (Dearnaley, 2007; Stewart et al., 2005). Mycorrhizal on plant roots can increase $\mathrm{Zn}$ and $\mathrm{S}$ absorption from ground faster than non-mycorrhizal root plants (Abbott et al., 1992; Michelsen \& Rosendahl, 1990). Application of VAM does not increase plant secondary metabolites production, such as saponin in Java ginseng tubers in this study. The mechanism of saponin biosynthesis or main function in plant are unclear until now (Santoso et al., 2016).

On the other hand, VAM application prevents rotten tuber. Rotten tuber can be detected by cut the tuber transversely. Healthy tubers do not have any spots on it when being cut transversely. Brown or red spots found in tuber when being cut indicate infection that can spread and root will become rotten. This result study shows that VAM application can prevents tuber damage caused by soil pathogens attack (Yadav et al., 2012; Sikes, 2010; Berta et al., 1995), such as fungi and nematodes (Michelsen \& Rosendahl, 1990). Previous study revealed that the existence of several fungi such as Glomus sp (Rianto, et al., 2005; Al-Karaki et al., 2004; Al-Karaki, 1998; Al-Karaki \& Al-Raddad, 1997). Futher research needed to be done specially to evaluate the nutrient uptake, physiology, and ginsenoside kinetics of Java ginseng under VAM inoculation in field

\section{Conclusions}

This study shown that VAM application on java ginseng prevents tuber damage caused by pathogen. However, there is no significant difference on dry biomass data and saponin levels of Java ginseng tuber between control and treatment group. Therefore, further 
research about the increasing of saponin level is needed, such as drought stress techniques.

\section{Acknowledgment}

This research has been funded by the Directorate of Higher Education, Ministry of Education and Culture of Indonesia and thanks to Febi Kurnia Putri for her excellent assistant in laboratory.

\section{References}

Abbott, L.K., Robson, A.D., Jasper, D.A. \& Gazey, C. 1992. What is the Role VAM Hyphae in Soil? In: Read DJ, Lewis DH, Fitter AH, Alexander IJ (eds). Mycorrhizas in Ecosystems. CAB International, UK: Oxford.

Al-Karaki, G.N \& Al-Raddad, A. 1997. Effects of Arbuscular Mycorrhizal Fungi and Drought Stress on Growth and Nutrient Uptake of Two Wheat Genotypes Differing in Drought Resistance. Mycorrhiza, 7:83-88.

Al-Karaki, G.N. 1998. Benefit, Cost and Water-Use Efficiency of Arbuscular Mycorrhizal Durum Wheat Grown under Drought Stress. Mycorrhiza, 8:41-45.

Al-Karaki, G.N, McMichael, B, \& Zak J. 2004. Field Response of Wheat to Arbuscular Mycorrhizal Fungi and Drought Stress. Mycorrhiza, 14:263-269.

Berta, G., Trotta, A., Fusconi, A., Hooker, J.A., Munro, M., Atkinson, D., Giovannetti, M., Morini, S., Fortuna, P., Tisserant, B., Gianinazzi-Pearson, F. \& Gianinazzi, S. 1995. Arbuscular Mycorrhizal Induced Changes to plant Growth and Root System Morphology in Prunus cerasifera. Tree Physiology, 15:281-293.

Dearnaley, J. 2007. Further Advances in Orchid Mycorrhizal Research. Mycorrhiza, 17(6):475486

Gazey, C., Abbott, L.K. \& Robson, A.D. 2004. Indigenous and Introduced Arbuscular Mycorrhizal Fungi Contribute to Plant Growth in Two Agricultural Soils from SouthWestern Australia. Mycorrhiza, 14:355-362.

Hu, X.Y., Neill, S.J., Cai, W.M. \& Tang, Z.C. 2003. Activation of Plasma Membrane NADPH Oxidase and Generation of $\mathrm{H}_{2} \mathrm{O}_{2}$ Mediate the Induction of PAL Activity and Saponin Synthesis by Endogenous Elicitor in Suspension-Cultured Cells of Panax Ginseng. Acta Botanica Sinica, 45(12):1434-1441.

Lakitan, B. 2007. Basics of Plant Physiology. Jakarta: PT Raja Grafindo Persada [in Indonesia].

Michelsen, A. \& Rosendahl, R. 1990. The Effect of VA Mycorrhizal Fungi, Phosphorus and Drought Stress on the Growth of Acacia nilotica and Leucaena leucocephala Seedlings. Plant and Soil, 124:7-13.

Nurhayati. 2010. Effect of time of administration of vesicular arbuscular mycorrhizal on tomato growth. J Agrivigor, 9:280-284 [In Indonesia].

Rahmi, Eriani, K. \& Widyasari, 2011. Potency of Java Ginseng (Talinum paniculatumGaertn.) Root Extract on Quality and Viability of Mice Sperm. Jurnal natural, 11:7-10.

Rianto, F., Hadi, S., Machmud, M. \& Fakuara, Y. 2005. Application of Glomus sp. for the Control Bacterial on Tomato. Biotrop special publication.

Ruiz-Lozano, J.M., Azcon, R. \& Gomez, R. 1995. Effects of Arbuscular-Mycorrhizal Glomus Species on Drought Tolerance: Physiological and Nutritional Plant Responses. Applied And Environmental Microbiology, 61(2):456-460.

Santoso, A.M. 2012. Effect of Elicitor Saccharomyces cerevisiae and CuSO4 Extracts on Biomass, Protein Profile, and Saponin Callus Content Talinum paniculatum (Jacq) Gaertn. 
Dissertation, Universitas Airlangga [in Indonesia].

Santoso, A.M., Amin, M., Sumitro, S.B. \& Lukiati, B. 2016. LCMS Determination of Java Ginseng (Talinum paiculatum) Ginsenoside. Proceeding of Second International Biology Conference: Institut Teknologi Sepuluh Nopember Surabaya.

Saroni N., Astuti Y. \& Adjirni. 1999. Influence of root infusion of Somjawa (Talinum paniculatum) to Amount and Motility of Spermatozoa in Mice. Warta Tumbuhan Obat Indonesia, 5:13-14 [In indonesia].

Setiadi, Y. 1989. Utilization of Microorganisms in Forestry. Departemen Pendidikan dan Kebudayaan Direktorat Jenderal Pendidikan Tinggi. Pusat Antar Universitas Bioteknologi IPB, Bogor, Indonesia [In Indonesia].

Sikes, B.A. 2010. When do Arbuscular Mycorrhizal Fungi Protect Plant Roots from Pathogens. Plant Signaling \& Behavior, 5(6):763-765.

Simanungkalit, R.D.M. 1997. Effectiveness of 10 species of Arbuskular Mycorrhizal Fungi Isolated from West Java and Lampung on Maize and Soybean. In: Jenie UA (ed) Indonesian Biotechnology Conference 1997: Proceeding of the Indonesian Biotechnology Consortium, IUC Biotechnology IPB, Bogor, Indonesia.

Stewart, L.I., Hamel, C., Hogue, R. \& Moutoglis, P. 2005. Response of Strawberry to Inoculation with Arbuscular Mycorrhizal Fungi under very High Soil Phosphorus Conditions. Mycorrhiza, 15:612-619.

Sumastuti, R. 1999. Effect of Inflammation of Leaf Infusion and Root of Somjawa (T. paniculatum) in White Rats in vitro. Warta Tumbuhan Obat Indonesia, 5:15-17 [[In Indonesia].

Winarni, D. 2009. Androgenic Potential of Ginseng Javan Root (Talinum paniculatum Gaertn.)

On Low Testosterone Conditions. Dissertation: Airlangga University [in Indonesia]

Yadav. K., Singh, N. \& Aggarwal, A. 2012. Arbuscular Mycorrhizal Technology for the Growth Enhancement of Micropropagated Spilanthes acmella Murr. Plant Protect. Sci., 48(1):3136.

\section{To cite this article:}

Sulistiono, Kristanti, A.N. \& Santoso, A.M. 2017. Talinum paniculatum (Jacq) Gaertn (Java ginseng) Production using Vesicular-Arbuscular Mycorrhizal. International Journal of Applied Biology. 1(2):76-81. 